3

\title{
Epidemiological characteristics of COVID-19 patients in Samarinda, East Kalimantan, Indonesia
}

\author{
Swandari Paramita ${ }^{1}{ }^{*}$, Ronny Isnuwardana ${ }^{1}$, Anton Rahmadi ${ }^{1}$, Osa Rafshodia ${ }^{2}$, Ismid \\ Kusasih ${ }^{2}$ \\ ${ }^{1}$ Center of Excellence for Tropical Studies, Mulawarman University, Samarinda, East \\ Kalimantan, Indonesia \\ ${ }^{2}$ Samarinda City Health Office, East Kalimantan, Indonesia \\ *Corresponding Author: s.paramita@fk.unmul.ac.id
}

\section{Abstract}

\section{Introduction}

Coronavirus Disease (COVID-19) is caused by SARS-CoV-2 infection. Indonesia announced the first COVID-19 case on 2 March 2020. East Kalimantan has been determined as the new capital of Indonesia since 2019. This makes Samarinda as the capital of East Kalimantan has been

17 focused for its capability of handling COVID-19 patients. We report the epidemiological characteristics and immunofluorescence assay results of these patients.

\section{Methods}

All patients with positive confirmed COVID-19 by RT-PCR were admitted to hospitals and quarantine center in Samarinda. We retrospectively analyzed data from the daily report of the Samarinda City and East Kalimantan Health Office information system.

\section{Results}

By June 25, 2020, 64 patients had been identified as having positive confirmed COVID-19. The mean age of the patients was $37.3 \pm 13.8$ years. Most of the patients were men (57 [90.6\%] patients). Thirty-nine COVID-19 patients were imported cases with a history of traveling from South Sulawesi. Most of the patients were admitted to the Quarantine Center of Samarinda City. The mean duration from the first hospital admission for isolation to discharge was 25.6 \pm 13.1 days. There was only one death case of COVID-19 patients in Samarinda. There were the highest confirmed cases of COVID-19 in Samarinda in early June 2020. There was a 
medRxiv preprint doi: https://doi.org/10.1101/2020.07.10.20151175; this version posted July 11 , 2020. The copyright holder for this preprint (which was not certified by peer review) is the author/funder, who has granted medRxiv a license to display the preprint in perpetuity.

It is made available under a CC-BY 4.0 International license .

31 declining trend in the age of COVID-19 patients and the duration of isolation time in the

32 hospital.

\section{Discussion}

34 Imported cases still contributed to the increase of COVID-19 cases in Samarinda. Younger age of COVID-19 patients was more involved in frequent mobility which makes them cause the spread of the disease. Activation of the national reference laboratory for the COVID-19 examination in Samarinda has reduced the length of time patients treated in hospitals.

\section{Conclusion}

The epidemiological characteristics of COVID-19 patients show the ability of local governments to deal with this pandemic. This can be seen from the low case fatality rate in

41 Samarinda.

\section{Introduction}

Coronavirus Disease (COVID-19) is caused by SARS-CoV-2 infection. Coronavirus is an RNA virus from the Coronaviridae family (1). Although most coronavirus infections are mild, there have been two epidemics of coronavirus in the past, namely severe acute respiratory coronavirus syndrome (SARS) (2) and Middle East respiratory syndrome coronavirus (MERS) (3), with a mortality rate of $10 \%$ for SARS (4) and $37 \%$ for MERS (5).

A series of pneumonia cases emerged in Wuhan, China, in December 2019, with clinical findings of viral pneumonia. (6). The analysis of patient samples indicates a new coronavirus, which was then named SARS-CoV-2 (7). Until the end of June 2020, the USA, Brazil, and Russia were the countries for the most COVID-19 cases in the world. There are more than 10 million positive confirmed cases worldwide (8).

On March 2, 2020, Indonesia announced the first case of COVID-19 (9). On March 18, 2020, the first case of COVID-19 in East Kalimantan was a patient from Samarinda (10). East Kalimantan province has been determined as the new capital of Indonesia by 2019 (11). This makes Samarinda as the capital of East Kalimantan has been focused for its capability of handling COVID-19 patients (12). Therefore, the study aims to describe the epidemiological characteristics of COVID-19 patients in Samarinda. 
medRxiv preprint doi: https://doi.org/10.1101/2020.07.10.20151175; this version posted July 11, 2020. The copyright holder for this preprint (which was not certified by peer review) is the author/funder, who has granted medRxiv a license to display the preprint in perpetuity.

It is made available under a CC-BY 4.0 International license .

63

64

65

66

67

68

69

70

71

72

73

This study was a descriptive analysis of all cases of COVID-19 diagnosed in Samarinda, East Kalimantan, Indonesia as of the end of June 25,2020 . This study was approved by the Ethical Health Research Commission of Faculty of Medicine Mulawarman University, Samarinda, Indonesia. Although individual informed consent was not required for this study, all data were handled to protect patient confidentiality and privacy.

\section{Data Source}

All data contained in all COVID-19 case records in the Samarinda City and East Kalimantan Health Office information system through the end of June 25,2020 , were extracted from the system. No sampling was done to achieve a predetermined study size and no eligibility criteria were used (all cases were included).

\section{Variables}

Patient characteristics were collected at the time of diagnosis and entry into the Samarinda City and East Kalimantan Health Office information system. All confirmed cases were diagnosed based on examination to confirm COVID-19 using reverse transcriptionpolymerase chain reaction (RT-PCR) according to guidelines from the Ministry of Health of the Republic of Indonesia. Some of the patients going through immunofluorescence assay (IFA) testing for immunoglobulin (Ig) $\mathrm{G}$ and $\mathrm{M}$ level.

\section{Analysis}

For all cases, epidemiological characteristics were summarized using descriptive statistics. Continuous variables were expressed as a mean and standard deviation; categorical variables were expressed as number (\%). Statistical analyses were done using Microsoft Excel.

\section{Results}

By June 25, 2020, 64 patients had been identified as having laboratory-confirmed COVID-19. Twenty-three (35.4\%) of the COVID-19 patients were aged 30-39 years. The mean age of the patients was $38.4 \pm 13.4$ years. Most of the infected patients were men (59 [90.8\%]). Thirtynine $(60 \%)$ of the COVID-19 patients in Samarinda were imported cases with a history of traveling from South Sulawesi. Most of the patients were admitted to Quarantine Center Samarinda City (39 [60\%]). The mean duration from COVID-19 laboratory confirmation to patient recovery was $15.2 \pm 10.5$ days. Patients with clinical improvement can be discharged from the hospital if the results of RT-PCR examination two days in a row show negative 
medRxiv preprint doi: https://doi.org/10.1101/2020.07.10.20151175; this version posted July 11, 2020. The copyright holder for this preprint (which was not certified by peer review) is the author/funder, who has granted medRxiv a license to display the preprint in perpetuity.

It is made available under a CC-BY 4.0 International license.

94 results. The case fatality rate was 0.02 . There was only one death case of COVID-19 patient in

95 Samarinda until June 25, 2020.

96

97 Table 1. Epidemiological characteristics of COVID-19 patients

98

\begin{tabular}{|c|c|}
\hline Characteristics & Mean \pm SD or $\mathbf{N}(\%)$ \\
\hline Age, years & $37.3 \pm 13.8$ \\
\hline$<10$ years & $2(3.1 \%)$ \\
\hline $10-19$ years & $1(1.6 \%)$ \\
\hline $20-29$ years & $16(25.0 \%)$ \\
\hline $30-39$ years & $21(32.8 \%)$ \\
\hline 40-49 years & $12(18.8 \%)$ \\
\hline $50-59$ years & $6(9.4 \%)$ \\
\hline $60-69$ years & $5(7.8 \%)$ \\
\hline$>69$ years & $1(1.6 \%)$ \\
\hline \multicolumn{2}{|l|}{ Sex } \\
\hline Men & $57(90.6 \%)$ \\
\hline Women & $7(10.9 \%)$ \\
\hline \multicolumn{2}{|l|}{ Mode of transmission imported cases } \\
\hline From South Sulawesi & $39(60.9 \%)$ \\
\hline From East Java & $7(10.9 \%)$ \\
\hline From Jakarta & $4(6.3 \%)$ \\
\hline From Central Kalimantan & $2(3.1 \%)$ \\
\hline From South Kalimantan & $2(3.1 \%)$ \\
\hline From North Maluku & $1(1.6 \%)$ \\
\hline From Regencies in East Kalimantan & $9(14.1 \%)$ \\
\hline \multicolumn{2}{|l|}{ Hospital admission of patients } \\
\hline AW Sjahranie Hospital (Province Hospital) & $16(25.0 \%)$ \\
\hline IA Moeis Hospital (City Hospital) & $4(6.3 \%)$ \\
\hline Quarantine Center of Samarinda City & $39(60.9 \%)$ \\
\hline Others & $5(7.8 \%)$ \\
\hline
\end{tabular}


medRxiv preprint doi: https://doi.org/10.1101/2020.07.10.20151175; this version posted July 11, 2020. The copyright holder for this preprint (which was not certified by peer review) is the author/funder, who has granted medRxiv a license to display the preprint in perpetuity.

It is made available under a CC-BY 4.0 International license .

99

100

101

102

103

104

105

106

\begin{tabular}{|l|l|}
\hline Case Fatality Rate (CFR) & 0.02 \\
\hline Days from isolation to discharge & $25.6 \pm 13.1$ \\
\hline RT-PCR testing & $64(100 \%)$ \\
\hline IFA testing & $47(73.4 \%)$ \\
\hline $\operatorname{IgG~(IU/mL)~}$ & $20.0 \pm 13.6$ \\
\hline $\operatorname{IgM}(\mathrm{IU} / \mathrm{mL})$ & $0.7 \pm 1.0$ \\
\hline
\end{tabular}

On the 12th week (June 3-9, 2020) there were the highest confirmed cases reaching 1.9 patients per day. This number has gradually declined in the following weeks (Figure 1). There is a declining trend in the age of COVID-19 patients, who are initially over 40 years old, later in their 30s (Figure 2). There is also a declining trend in the duration of admission time in the hospital, which initially can last more than 3 weeks, later to be around one week only (Figure $3)$.

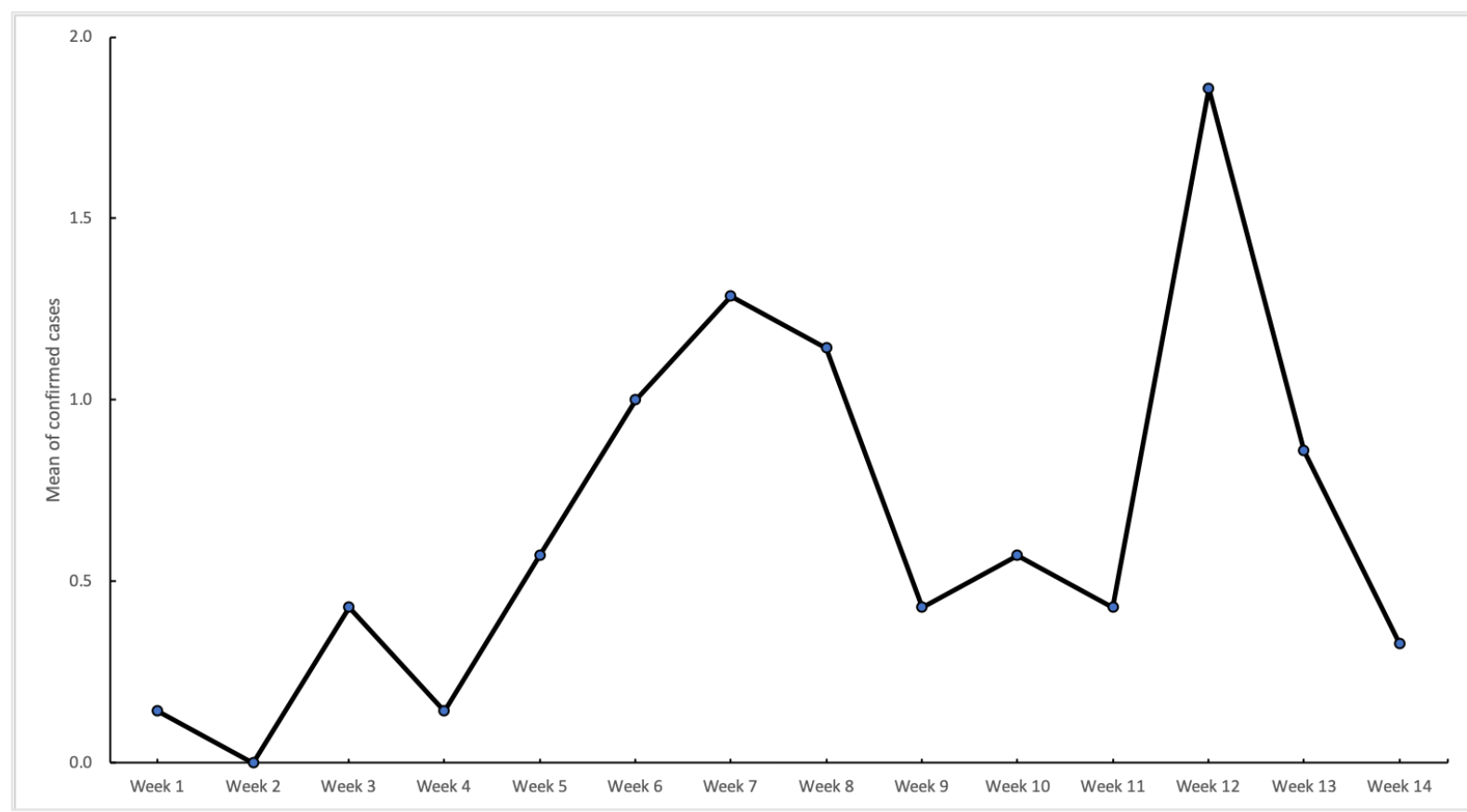

Figure 1. The weekly mean for confirmed cases of COVID-19 in Samarinda (March 18 to June $25,2020)$ 
medRxiv preprint doi: https://doi.org/10.1101/2020.07.10.20151175; this version posted July 11,2020 . The copyright holder for this preprint (which was not certified by peer review) is the author/funder, who has granted medRxiv a license to display the preprint in perpetuity.

It is made available under a CC-BY 4.0 International license.

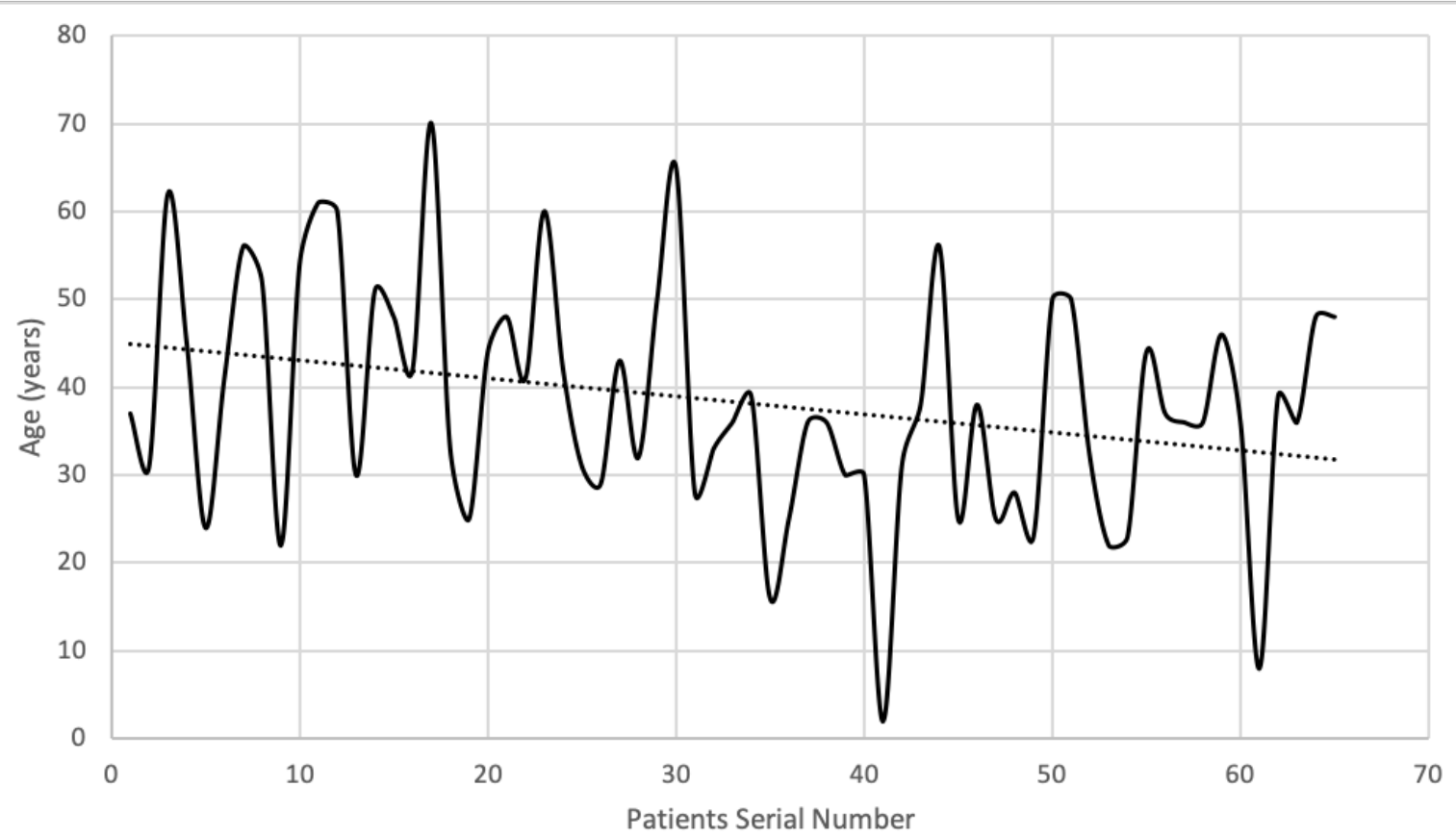

113 Figure 2. Age trend for confirmed cases of COVID-19 in Samarinda

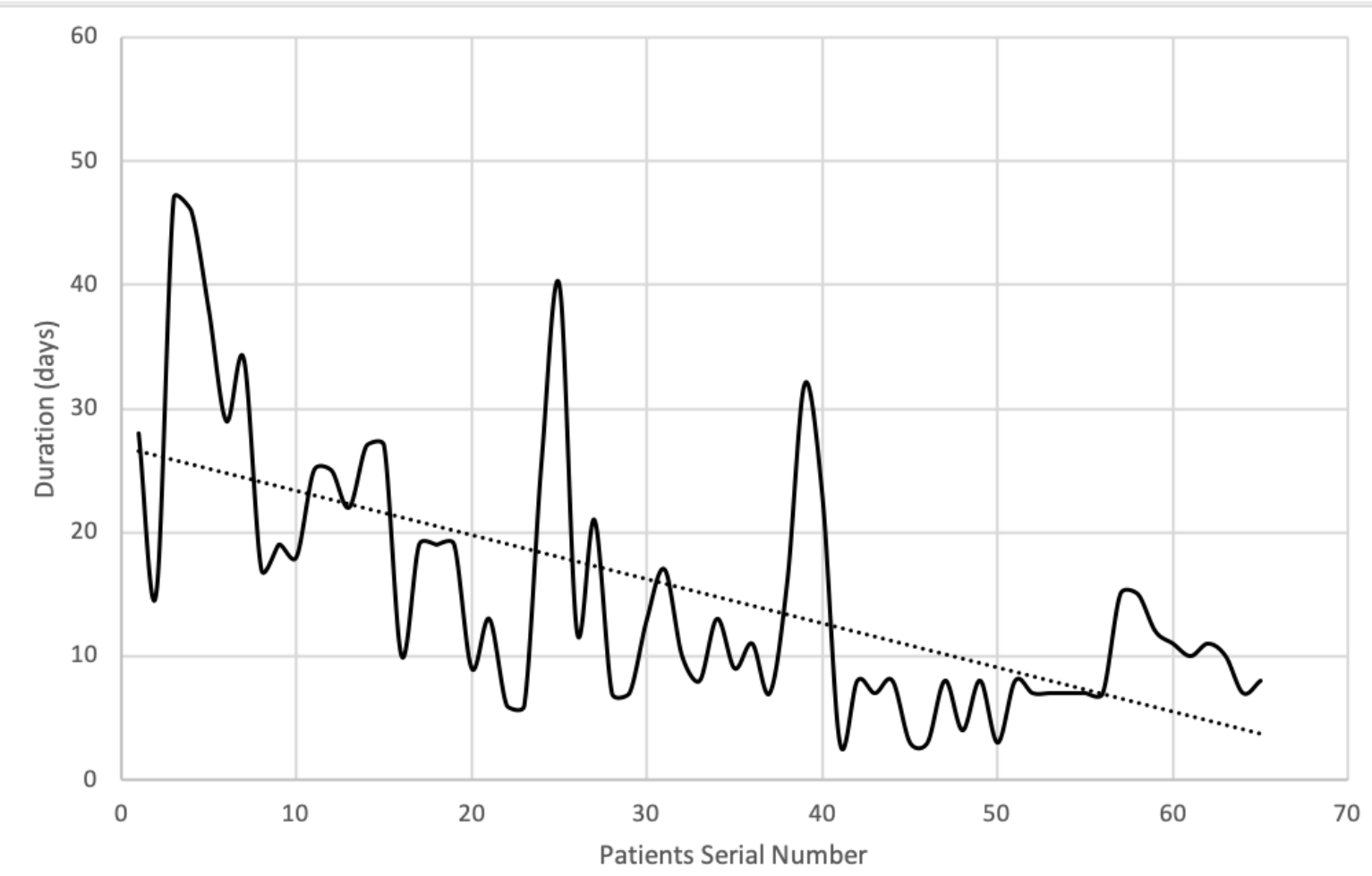

116 Figure 3. Duration of hospital admission trend for confirmed cases of COVID-19 in Samarinda 
medRxiv preprint doi: https://doi.org/10.1101/2020.07.10.20151175; this version posted July 11, 2020. The copyright holder for this preprint (which was not certified by peer review) is the author/funder, who has granted medRxiv a license to display the preprint in perpetuity.

It is made available under a CC-BY 4.0 International license.

119 This study reports a study of 64 patients with positive COVID-19 in Samarinda, East

120 Kalimantan, Indonesia. As of June 25, 2020, 100 days after the first confirmed case in

121 Samarinda, there have been 473 positive COVID-19 positive cases in East Kalimantan (13). To

122 date, there are 50,178 positive confirmed cases of COVID-19, with 20,449 people recovering

123 and 2,620 patients have died in Indonesia (14). Most of the infected patients were aged 30-

12439 years. These results are similar to previous studies at Abdul Wahab Sjahranie Hospital

125 Samarinda which showed that most patients were also in this age group (15). There is a

126 declining trend for the younger age of COVID-19 patients. Young adults are more involved in

127 frequent social activity and mobility which makes them cause the spread of COVID-19 (16).

128 The majority of COVID-19 patients in Samarinda are male. This is consistent with a meta-

129 analysis study which showed that men took the largest percentage in the distribution of

130 COVID-19 according to gender (17).

131 Sixty percent of the COVID-19 patients in Samarinda were imported cases with a history of

132 traveling from South Sulawesi. Travel history of attending religious activities in Gowa, South

133 Sulawesi a few months ago contributed greatly to the positive confirmed case in Samarinda

134 (18). The cluster of ship crews and shipping agents from South Sulawesi also added the

135 number of imported cases from there. South Sulawesi is one of the three new epicenter

136 COVID-19 in Indonesia, along with South Kalimantan and East Java. The emergence of this

137 new epicenter occurred in early June 2020, together with the time of the highest confirmed

138 COVID-19 cases in Samarinda on the 12th week between 3-9 June 2020 (19).

139 Most of the patients were admitted to the Quarantine Center of Samarinda City. As of June

14025,2020 , only 1 fatal case of confirmed COVID-19 was reported in Samarinda, with CFR 0.02

141 (13). Most of the COVID-19 patients admitted to hospitals in Samarinda are in mild condition.

142 Quarantine center was established to treat people without symptoms, so the referral hospital

143 will not be full of COVID-19 patients and focus on treating patients with more serious

144 conditions (20).

145 The average length of laboratory positive COVID-19 to hospital discharge is more than 15 146 days. This is because COVID-19 patients with clinical improvement can only be discharged

147 from the hospital if the results of RT-PCR examination two days in a row show negative results

148 (21). Before the end of May 2020, the nasopharyngeal swab sample from East Kalimantan

149 being sent to the Center for Health Laboratory of the Ministry of Health in Surabaya,

150 Indonesia. This laboratory serves the examination of reference specimens from the provinces 
medRxiv preprint doi: https://doi.org/10.1101/2020.07.10.20151175; this version posted July 11 , 2020. The copyright holder for this preprint (which was not certified by peer review) is the author/funder, who has granted medRxiv a license to display the preprint in perpetuity.

It is made available under a CC-BY 4.0 International license .

151 of East, Central, South, and North Kalimantan (12). The large number of samples that have to

152 be examined up to 4 provinces makes the slow progress of laboratory examination. Patients

153 must wait a long time for laboratory confirmation results of COVID-19 (22). From May 21,

154 2020, there are 3 national reference laboratories for the COVID-19 examination in East

155 Kalimantan, namely Abdul Wahab Sjahranie Hospital Samarinda, Kanujoso Djatiwibowo, and

156 Pertamina Hospital Balikpapan (23). Since then the length of time patients have been

157 hospitalized has been reduced from the initial 3 weeks to one week.

158

\section{Conclusion}

160 Imported cases still contributed to the increase of COVID-19 cases in Samarinda. Younger age

161 of COVID-19 patients was more involved in frequent mobility which makes them cause the spread of COVID-19. Activation of the national reference laboratory for the COVID-19 examination in Samarinda has reduced the length of time patients treated in hospitals. The epidemiological characteristics of COVID-19 patients show the ability of local governments to deal with this pandemic. This can be seen from the low case fatality rate in Samarinda.

\section{REFERENCES}

168 1. Richman D, Whitley R, Hayden F. Clinical Virology. 4th ed. Washington: ASM Press; 2016.

170 2. Drosten C, Günther S, Preiser W, Van Der Werf S, Brodt HR, Becker S, et al. Identification of a novel coronavirus in patients with severe acute respiratory syndrome. N Engl J Med. 2003;348(20):1967-76.

3. Zaki AM, Van Boheemen S, Bestebroer TM, Osterhaus AD, Fouchier RA. Isolation of a novel coronavirus from a man with pneumonia in Saudi Arabia. N Engl J Med. 2012;367(19):1814-20.

4. WHO. Summary of probable SARS cases with onset of illness from 1 November 2002 to 31 July 2003. World Health Organization. 2003.

178 5. WHO. Middle East respiratory syndrome coronavirus (MERS-CoV). World Health Organization. 2019.

180 6. WHO. Novel Coronavirus - China. World Health Organization. 2020.

181 7. Gorbalenya AE. Severe acute respiratory syndrome-related coronavirus-The species and its viruses, a statement of the Coronavirus Study Group. BioRxiv. 2020; 
medRxiv preprint doi: https://doi.org/10.1101/2020.07.10.20151175; this version posted July 11 , 2020. The copyright holder for this preprint (which was not certified by peer review) is the author/funder, who has granted medRxiv a license to display the preprint in perpetuity.

It is made available under a CC-BY 4.0 International license .

183 8. Worldometer. COVID-19 Coronavirus Pandemic. Worldometer. 2020.

184 9. Gorbiano MI. BREAKING: Jokowi announces Indonesia's first two confirmed COVID-19 cases. The Jakarta Post. 2020 Mar 2;

10. Kumparan. Kasus Positif Corona Pertama di Kaltim, Pasien Pernah Ikut Seminar di Bogor. Kumparan. 2020 Mar 18;

11. Maulia E. Jokowi announces Indonesia's new capital in East Kalimantan. Nikkei Asian Review. 2019 Aug 26;

12. Ministry of Health Republic of Indonesia. COVID-19. Infeksi Emerging. 2020.

13. Dinas Kesehatan Provinsi Kalimantan Timur. Dinas Kesehatan Provinsi Kalimantan Timur [Internet]. COVID-19. 2020. Available from: https://covid19.kaltimprov.go.id

14. Kementerian Kesehatan RI. Situasi Terkini Perkembangan Coronavirus Disease (COVID19). Kementerian Kesehatan RI. 2020.

15. Paramita S, Isnuwardana R, Marwan M, Alfian DI, Masjhoer DH. Clinical features of COVID-19 patients in Abdul Wahab Sjahranie Hospital, Samarinda, Indonesia. medRxiv. 2020;

16. Liao J, Fan S, Chen J, Wu J, Xu S, Guo Y, et al. Epidemiological and clinical characteristics of COVID-19 in adolescents and young adults. Innov. 2020;1(1):100001.

18. Rismayani R. Public Response for Information and Education Systems Prevent Spread of COVID-19 on Maros District Government Website Page: A Survey. SSRN. $2020 ; 3575840$.

19. World Health Organization. Coronavirus Disease 2019 ( COVID-19) Situation Report 13. 2020.

20. Djalante R, Lassa J, Setiamarga D, Mahfud C, Sudjatma A, Indrawan M, et al. Review and analysis of current responses to COVID-19 in Indonesia: Period of January to March 2020. Prog Disaster Sci. 2020;100091.

21. Direktorat Jenderal Pencegahan dan Pengendalian Penyakit. Pedoman Pencegahan dan Pengendalian Coronavirus Disease (COVID-19). Jakarta, Indonesia: Kementerian Kesehatan Rl; 2020.

22. Gugus Tugas Percepatan Penanganan COVID-19. Situasi virus COVID-19 di Indonesia. 
medRxiv preprint doi: https://doi.org/10.1101/2020.07.10.20151175; this version posted July 11 , 2020. The copyright holder for this preprint (which was not certified by peer review) is the author/funder, who has granted medRxiv a license to display the preprint in perpetuity.

It is made available under a CC-BY 4.0 International license .

Gugus Tugas Percepatan Penanganan COVID-19. 2020.

216 23. Badan Nasional Penanggulangan Bencana. 129 Laboratorium Rujukan Nasional covid19 